\title{
21 Reducing the impact of mycotoxigenic fungi on food safety and security in Southern Africa
}

\author{
Juliet Akello, George Mahuku, Lindy Rose, \\ Altus Viljoen, David Chikoye D., \\ Pheneas Ntawuruhunga, Katati Bwalya \\ and Ranajit Bandyopadhyay
}

\section{Introduction}

The spoilage of food by filamentous fungi is a substantial problem in sub-Saharan Africa, with pre- and postharvest losses estimated at 15-100\% and amounting to about US $\$ 4$ billion per annum (Hodges et al., 2011; Affognon et al., 2015). Some fungi may produce toxic secondary metabolites in food and feed, called mycotoxins (Hoopwood and Sherman, 1990), thereby rendering them unsafe for humans and livestock. To date, over 500 types of mycotoxins have been reported, with some fungi being able to produce more than one mycotoxin and some mycotoxins being produced by more than one fungal species.

Worldwide, aflatoxins, trichothecenes, fumonisins, zearalenone, ochratoxin, patulin and ergot alkaloids are considered the most economically and toxicologically important mycotoxins (Bennett and Klich, 2003; Richard, 2007). These mycotoxins are produced by toxigenic fungal species. In the Southern African Development Community (SADC), toxigenic fungal species belonging to Fusarium, Aspergillus, Alternaria and Penicillium genera are common in farmland soils, crop debris and foodstuffs (Probst et al., 2014; Kachapulula et al., 2017).

Cereal grains (maize, wheat, sorghum and millet), legume grains (peanuts), tree nuts, wild fruits and insects that are traded in the SADC region are not only hosts of toxigenic fungi, but can also be contaminated with multiple mycotoxins (Probst et al., 2014; Udomkun et al., 2017; Nleya et al., 2018; Kachapulula et al., 2018; Misihairabgwi et al., 2019) (Table 21.1). Conducive environmental conditions, poor agronomic practices, improper drying before storage, insect damage, poor storage facilities, unhygienic handling of produce and informal markets worsen the mycotoxin problem in food and feed value chains (Affognon et al., 2015). Consequently, mycotoxin exposure through eating contaminated food is high in the SADC region (Lauer et al., 2019), posing a significant health hazard to consumers. 
Table 21.1 Summary of major mycotoxins reported in cereals and peanuts that were produced and traded in Southern Africa

\begin{tabular}{|c|c|c|c|c|}
\hline Mycotoxin type & $\begin{array}{l}\text { Food } \\
\text { commodity }\end{array}$ & SADC Country & $\begin{array}{l}\text { Maximum level } \\
(\mu g / \mathrm{kg})\end{array}$ & Reference \\
\hline \multirow[t]{6}{*}{ Total aflatoxin } & \multirow{2}{*}{$\begin{array}{l}\text { Maize and } \\
\text { maize } \\
\text { products }\end{array}$} & Malawi & 140 & $\begin{array}{l}\text { Mwalwayo and Thole, } \\
2016\end{array}$ \\
\hline & & $\begin{array}{l}\text { Zambia/ } \\
\text { Zimbabwe }\end{array}$ & $108 / 123$ & Probst et al., 2014 \\
\hline & Sorghum beer & Malawi & 1139 & Matumba et al., 2011 \\
\hline & $\begin{array}{l}\text { Peanuts and } \\
\text { peanut } \\
\text { butter }\end{array}$ & Malawi & 500 & Matumba et al., 2014 \\
\hline & peanut butter & Zimbabwe & 622 & Mupunga et al., 2014 \\
\hline & Peanut grain & South Africa & 131 & Ncube et al., 2010 \\
\hline \multirow[t]{6}{*}{ Aflatoxin B1 } & \multirow{4}{*}{$\begin{array}{l}\text { Maize and } \\
\text { maize } \\
\text { products }\end{array}$} & Mozambique & 636 & Warth et al., 2012 \\
\hline & & Zimbabwe & 26.6 & $\begin{array}{l}\text { Hove et al., 2016; } \\
\text { Murashiki et al., } \\
2017\end{array}$ \\
\hline & & South Africa & 741 & Mngqawa et al., 2016 \\
\hline & & Lesotho & 3500 & Mohale et al., 2013 \\
\hline & peanut butter & Zambia & 10000 & Njoroge et al., 2016 \\
\hline & peanut grain & South Africa & 35.39 & Kamika et al., 2014 \\
\hline \multirow[t]{5}{*}{$\begin{array}{l}\text { Fumonisin } \\
\text { (total) }\end{array}$} & \multirow{4}{*}{$\begin{array}{l}\text { Maize and } \\
\text { maize } \\
\text { products }\end{array}$} & $\begin{array}{l}\text { Malawi/ } \\
\text { Mozambique }\end{array}$ & $9000 / 10000$ & Probst et al., 2014 \\
\hline & & Zambia & 192000 & Mukanga et al., 2010 \\
\hline & & Zimbabwe & 159000 & Probst et al., 2014 \\
\hline & & South Africa & 142800 & $\begin{array}{l}\text { Mngqawa et al., 2016; } \\
\text { Rheeder et al., 2016 }\end{array}$ \\
\hline & Sorghum & Zimbabwe & 187 & Mupunga et al., 2014 \\
\hline \multirow[t]{4}{*}{ FB1 } & \multirow{4}{*}{$\begin{array}{l}\text { Maize and } \\
\text { maize } \\
\text { products }\end{array}$} & Mozambique & 7615 & Warth et al., 2012 \\
\hline & & Zimbabwe & 1106 & $\begin{array}{l}\text { Hove et al., 2016; } \\
\text { Murashiki et al., } \\
2017\end{array}$ \\
\hline & & South Africa & 14990 & Shephard et al., 2013 \\
\hline & & Lesotho & 936 & Mohale et al., 2013 \\
\hline Zeralenone & Maize & Zimbabwe & 369 & Hove et al., 2016 \\
\hline \multirow[t]{2}{*}{$\begin{array}{l}\text { Deoxynivalenol } \\
\text { (DON) }\end{array}$} & Maize & $\begin{array}{l}\text { Zimbabwe/ } \\
\text { South Africa }\end{array}$ & $492 / 960$ & Hove et al., 2016 \\
\hline & Wheat flour & South Africa & 100 & Shephard et al., 2010 \\
\hline
\end{tabular}

\section{Potential negative impacts of mycotoxins in the SADC region}

Chronic exposure to mycotoxins (especially aflatoxins, ochratoxin A, fumonisins and ergot alkaloids) may result in health problems such as liver, renal and esophagus cancers, retarded child growth, weakened immunity, reduced fertility, damaged nervous system, egotism and neural tube effects in humans (Wu and Khlangwiset, 2010; Hove et al., 2016; Eze et al., 2018; Lauer et al., 2019) 
(Figure 21.1A, 21.1B). Mycotoxins can also be fatal if high quantities are ingested (Richard, 2007; Shephard, 2008; Kamala et al., 2018). The consumption of aflatoxin-contaminated foods in Southern Africa, for example, was noted to result in child undernutrition, increased morbidity and mortality due to suppressed

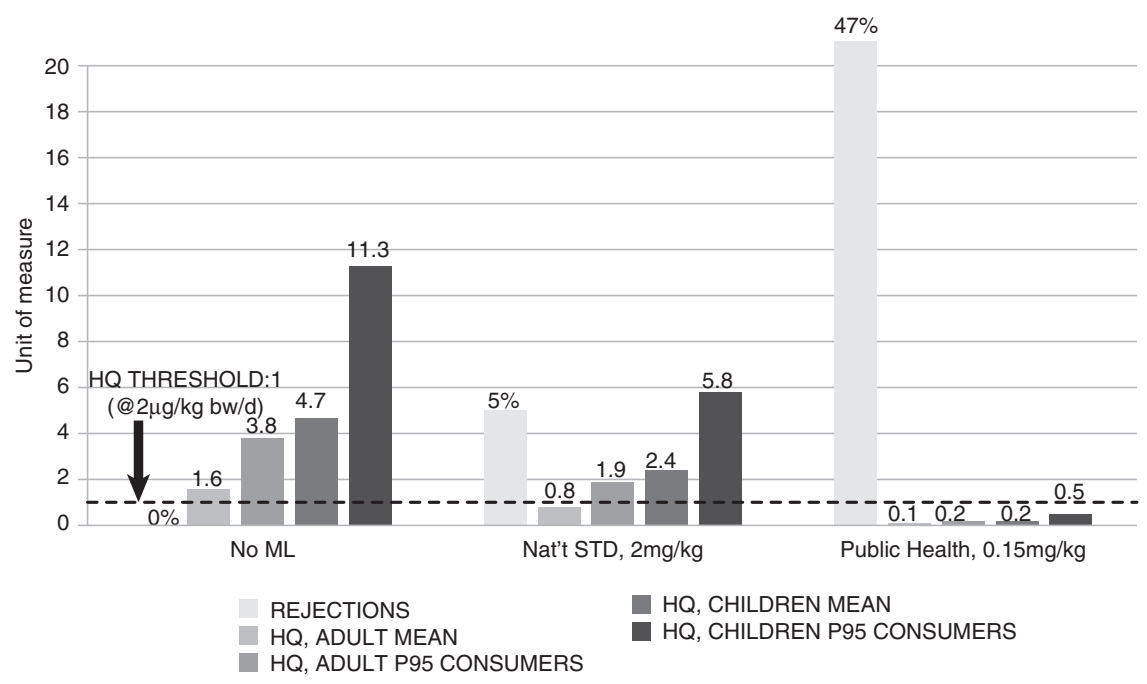

Figure 21.1a Potential impact of fumonisin B1 contamination of maize grain on the health and trade in Zambia; HQ represents "Hazard Quotient"

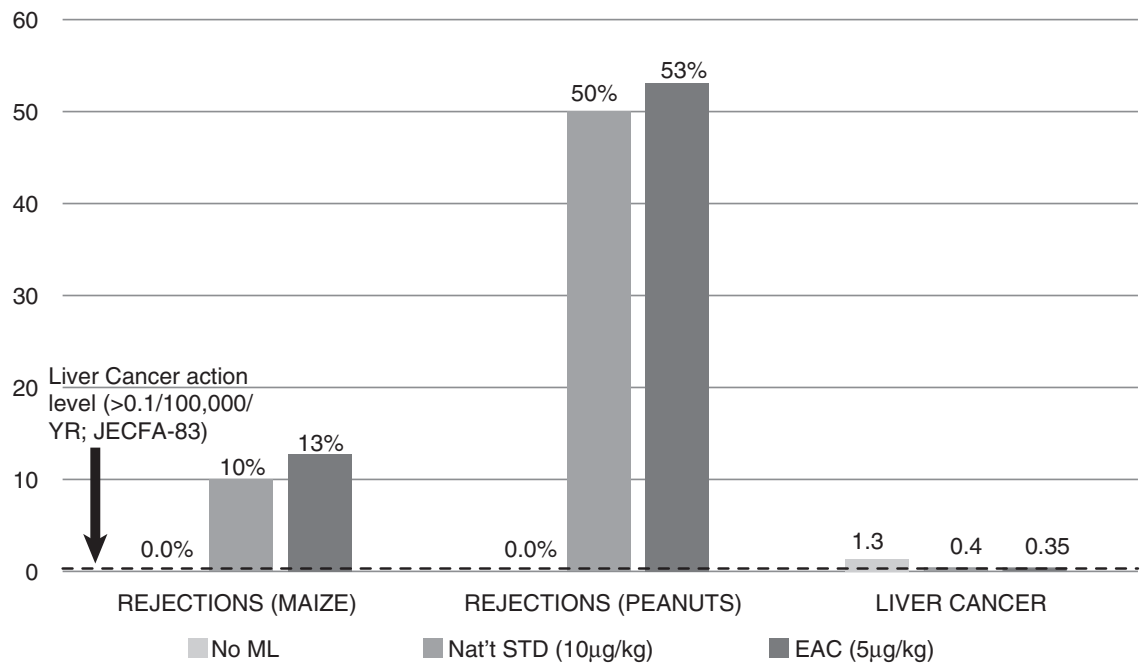

Figure 21.1b Potential impact of aflatoxin B1 contamination of maize and peanuts on health and trade in Zambia 
immunity and micronutrient malabsorption (Katerere et al., 2008). The stringent mycotoxin standards set internationally also affects international trade as it prevents access of African products to premium markets in Europe and the U.S. The decrease in productivity, and investments made to mitigate aflatoxins, fumonisins and trichothecenes exposure in Africa, is estimated at US\$1 billion and US\$500 million per annum, respectively (Wu, 2015).

\section{Mitigation strategies for mycotoxins and challenges}

Two review papers that appeared in 2011 alluded to the fact that the global food crisis, including hunger, malnutrition and poverty, can be minimized by addressing pre- and postharvest losses (Foresight, 2011; World Bank, 2011). In Southern Africa, this could include a reduction in mycotoxin-related losses by using appropriate and cost-effective technologies, investments in proper policies, access to finance, pest and disease management, extension and infrastructure.

\section{Prevention and control of mycotoxins in foods}

Periodic surveillance, creating awareness and advocacy for safer foods remain a top measure for facilitating behavioural, attitude and mindset changes for reduced mycotoxin contamination and exposure risks (Gelayee et al., 2017). Throughout SSA, limited information is available on the extent of mycotoxins contamination in major staple foods.

\section{Prevention and management of mycotoxins in foods}

Information on the extent of mycotoxin contamination in major staple food crops in sub-Saharan Africa is limited with testing crops for mycotoxin contamination mainly limited to maize and peanuts, while the contamination of sorghum and millet has been neglected. SADC governments, thus, need to invest in affordable mycotoxin testing services and the routine analysis of mycotoxin-susceptible or -affected commodities. People should be made aware of the contamination of food with toxins, and the consumption of safe foods should be advocated for. Mycotoxin-prone areas need to be identified using climatic data, and information needs to be provided for the appropriate management of mycotoxigenic fungi. Developing and harmonizing community sensitization messages and platforms will remain key to effectively communicate the harmful effects of mycotoxins and demonstrate the benefits of available solutions to stakeholders involved in the food and feed value chains.

Good agronomic practices and detoxification of contaminated crops constitute some of the mitigation measures used to restrict mycotoxin contamination of food and feed. Simple agronomic practices like timely planting and harvest at the correct maturity, avoidance of water and nutrient stress through proper irrigation and fertigation schedules, crop rotation and minimizing insect damage can lower fungal infestation and subsequent mycotoxin contamination in 
farm produce (Matumba et al., 2018; Ojiambo et al., 2018; Mukanga et al., 2019). The use of quality seed and mycotoxin-resistant crop varieties may also reduce contamination (Fox and Howlett, 2008). Enormous efforts are currently being made to breed mycotoxin-resistant crop varieties; however, most maize or peanut varieties grown in sub-Saharan Africa are susceptible to fumonisins and aflatoxins, respectively (Fox and Howlett, 2008). The high costs associated with mycotoxin management may hinder adoption of interventions by subsistence farmers. Nonetheless, the planting of drought-tolerant and insect-resistant varieties, in combination with good agronomic and postharvest handling practices, may be valuable for the integrated management of mycotoxin contamination in grains.

The use of appropriate drying techniques and proper storage facilities, along with proper handling of harvested produce during transportation, can minimize mycotoxin contamination in grains. In developed countries, mechanical driers are used to reduce grain moisture content to safe levels $(<12 \%$ for maize and $9 \%$ for peanuts), which prevents fungal growth and mycotoxin contamination in food. In the developing countries including sub-Saharan Africa, smallholder farmers use natural sun-drying in the field, a method that may increase mycotoxin levels depending on the technique and drying duration (Matumba et al., 2018). Storage technologies that limit pest or pathogen multiplication in stored grains, such as hermetic facilities, the Purdue Improved Crop Storage (PICS) bags, cocoons and metallic/ plastic silos - instead of dirty polyethylene bags and rudimentary granaries - help to reduce mycotoxin contamination in stored grain.

The reduction of fungal inoculum in environments where agricultural commodities are produced, transported, processed and stored can prevent preand postharvest crop losses due to harmful microbes. The use of antagonistic microorganisms with fungicidal or bactericidal properties to suppress and out-compete harmful microbes are often used to mitigate crop losses (Sharma et al., 2009; Velmourougane et al. 2011). In this respect, non-toxin producing strains of Aspergillus flavus has been used with great success to reduce aflatoxins in maize and peanuts (Dorner, 2004, 2009; Bandyopadhyay et al., 2016). Atoxigenic A. flavus strains are now widely used in sub-Saharan Africa, including SADC countries, to reduce aflatoxin contamination in maize and peanuts (Bandyopadhyay et al., 2016). In Zambia, countrywide field efficacy trials in peanut fields, for example, demonstrated that the aflasafe biocontrol product can reduce aflatoxin contamination in all agro-ecological zones including areas that receive low amounts of rainfall leading to reduced losses (Table 21.2).

\section{Removal of mycotoxins in foods}

Hand-sorting or the use of mechanical sorters to remove insect-infested, or shriveled, rotten and discoloured grains from healthy kernels as well as washing and dehulling are effective means of reducing mycotoxins from agricultural commodities (Matumba et al., 2015). Mycotoxigenic fungi and their toxins can also be decontaminated, degraded, deactivated and detoxified by using physical, 
Table 21.2 The effect of aflasafe biocontrol product on the health of peanut consumers, trade and potential food losses in Zambia

\begin{tabular}{lccc}
\hline Category & Untreated & Aflasafe treated & $\%$ Reduction \\
\hline Samples size & 250 & 250 & - \\
Min (ppb) & $<2$ & $<2$ & - \\
Max (ppb) & 7,205 & 3,168 & - \\
Overall mean (ppb) & 220 & 35 & 84 \\
\% samples $>4 \mathrm{ppb}^{\star}$ & 38.4 & 20 & 48 \\
\% samples $>10 \mathrm{ppb}^{\star}$ & 34 & 16.4 & 52 \\
\% samples $>100 \mathrm{ppb}^{\star}$ & 20.8 & 6.4 & 69 \\
\% samples $>1000 \mathrm{ppb}^{\star}$ & 6 & 1.2 & 80 \\
\hline
\end{tabular}

$\%$ samples $>\star$ ppb - Reflects effect on trade or health of consumers or potential food losses and not the effect of aflasafe in the category (row)

chemical or biological treatments. These include modified atmosphere packaging, irradiation, thermal treatment, nixtamalization, ammoniation and the addition of binders to destroy toxigenic microbes and deactivate mycotoxins (Kabak et al., 2006; Fox and Howlett, 2008; Schmidt et al., 2018). Some of these interventions, however, are costly and may only be suitable (e.g., binders) for animal feeds, as they are unsafe for food treatment (Fox and Howlett, 2008).

\section{Policies, legislations and regulations on mycotoxins in foods}

Legislation exists in most developed countries to regulate mycotoxin levels in food (Streit et al., 2012). In sub-Saharan Africa, however, food safety policies, legislations and regulations are either nonexistent or, when available, limited to a few mycotoxins such as aflatoxins, ergot alkaloids, deoxynivalenol and ochratoxins only. Even if existing this legislation is seldom enforced, thereby discouraging the trade of safe foods nationally and internationally and, as a result, undermining economic growth on the continent (FAO, 2016). SADC countries, therefore, should sincerely review their food safety and nutrition programmes if they are sincere in reducing the contamination of food with mycotoxins and committed to trading African crops on international markets.

\section{Conclusion}

Mycotoxin contamination is an invisible problem, and in many cases, there are no visible symptoms. Often, farmers, traders, processors and consumers are unaware of mycotoxin problem nor potential health risks. Where people are aware of the problem, the lack of easily accessible and cheap tools to measure the level of contamination and the lack of market or legislative incentives to produce aflatoxin-free commodities means that the problem is largely ignored. There is an urgent need to develop and make available to farmers technological solutions that can help them produce mycotoxin-free commodities and processors 
produce mycotoxin-free products. Low-cost, robust mycotoxin assaying tools are required to monitor mycotoxin contamination of important staples and use the data for risk mapping and targeting of intervention strategies. Several approaches are available for the integrated management of mycotoxins. These range from regulation, good agricultural practices, use of resistant cultivars, biological control through competitive exclusion and good storage practices. Despite the benefits, uptake of those measures is low due to inadequate capacity in terms of knowledge, facilities and financial resources. Strict regulation works well in developed countries; however, this approach is not practical for developing countries that lack the tools, resources and expertise to enforce it. Agronomic practices that require extra time to manage from the farmers are not practical. Creating awareness of mycotoxins and health impact is required to catalyze and stimulate behavioural change to stimulate stakeholders demand for mycotoxin-free products and contribute to nutritional and food safety and reduced health burden from mycotoxin exposure. Incorporating aspects of mycotoxin control into the curriculum of relevant educational/training institutions, capacity building on mycotoxin surveillance and testing, as well as enforcing policies that support production and trade of mycotoxin-safe commodities will offer access to safe food and premium markets.

\section{References}

Affognon, H., Mutungi, C., Sanginga, P. and Borgemeister, C. (2015) Unpacking postharvest losses in Sub-Saharan Africa - A meta-analysis. World Development vol 66, pp. 49-68.

Bandyopadhyay, R., Ortega-Beltran, A., Akande, A., Mutegi, C., Atehnkeng, J., Kaptoge, L., Senghor, A.L., Adhikari, B.N. and Cotty, P.J. (2016) Biological control of aflatoxins in Africa: current status and potential challenges in the face of climate change. World Mycotoxin Journal, 9, pp. 771-789.

Bennett, J.W. and Klich, M. (2003) Mycotoxins. Clinical Microbiology Reviews, vol 16, no 5, pp. 497-516.

Dorner, J.W. (2004) Biological control of aflatoxin contamination of crops. Toxin Reviews, vol 3, nos 2-3, pp. 425-450.

Dorner, J.W. (2009) Biological control of aflatoxin contamination in corn using a nontoxigenic strain of Aspergillus flavus. Journal of Food Protection, vol 72, no 4, pp. 801-804.

Eze, U.A., Routledge, M.N., Okonofua, F.E., Huntriss, J. and Gong, Y.Y. (2018) Mycotoxin exposure and adverse reproductive health outcomes in Africa: A review. World Mycotoxin Journal, vol 11, no 3, pp. 321-339.

FAO (2016) Report of the '2015 Series of International Conferences on Food Loss and Waste Reduction' - Recommendations in Improving Policies and Strategies for Food Loss and Waste Reduction. FAO Rome, IT. www.fao.org/3/a-bc345e.pdf.

Foresight (2011) The Future of Food and Farming-Final Project Report. The Government Office for Science, London, 208pg.

Fox, E.M. and Howlett, B.J. (2008) Secondary metabolism: Regulation and role in fungal biology. Current Opinion in Microbiology, vol 11, pp. 481-487.

Gelayee, D.A., Mekonnen, G. B. and Atnafe, S.A. (2017) Practice and barriers towards provision of health promotion services among community pharmacists in Gondar, Northwest Ethiopia. BioMed Research International, doi:10.1155/2017/7873951. 
Hodges, R.J., Buzby, J.C. and Bennett, B. (2011) Postharvest losses and waste in developed and less developed countries - Opportunities to improve resource use. Journal of Agricultural Science, vol 149, pp. 37-45.

Hoopwood, D.A. and Sherman, D.H. (1990) Molecular genetics of polyketides and its comparison to fatty acid biosynthesis. Annual Review of Genetics, Palo Alto, vol 34, pp. 37-62.

Hove, M., Van Poucke, C., Njumbe-Ediage, E., Nyanga, L. and De Saeger, S. (2016) Review on the natural cooccurrence of $\mathrm{afb} 1 \mathrm{and} \mathrm{fb} 1$ in maize and the combined toxicity of AFB1 and FB1. Food Control, vol 59, pp. 675-682.

Kabak, B., Dobson, A.D. and Var, I. (2006) Strategies to prevent mycotoxin contamination of food and animal feed: A review. Critical Reviews in Food Science and Nutrition, vol 46, pp. 593-619.

Kachapulula, W.P., Akello, J., Bandyopadhyay, R. and Cotty, P.J. (2017) Aspergillus section Flavi community structure in Zambia influences aflatoxin contamination of maize and groundnut. International Journal of Food Microbiology, vol 261, pp. 49-56.

Kachapulula, W.P., Akello, J., Bandyopadhyay, R. and Cotty, P.J. (2018). Aflatoxin contamination of dried insects and fish in Zambia. Journal of Food Protection, vol 81, pp. 1508-1518.

Kamala, A., Shirima, C., Jani, B., Bakari, M., Sillo, H., Rusibamayila, N., De Saeger, S., Kimanya, M., Gong, Y.Y. and Simba, A. (2018) Outbreak of an acute aflatoxicosis in Tanzania during 2016. World Mycotoxin Journal, 11, no 3, pp. 311-320.

Kamika, I., Mngqawa, P., Rheeder, J.P., Teffo, S.L. and Katerere, D.R. (2014) Mycological and aflatoxin contamination of peanuts sold at markets in Kinshasa, Democratic Republic of Congo, and Pretoria, South Africa. Food Additives and Contaminants: Part B, vol 7, no 2, pp. 120-126.

Katerere, D.R., Shephard G.S. and Faber, M. (2008) Infant malnutrition and chronic aflatoxicosis in Southern Africa: Is there a link? International Journal of Food Safety Nutrition and Public Health, 1, no 2, pp. 127-136.

Lauer, J.M., Duggan, C.P., Ausman, L.M., Griffiths, J.K., Webb, P., Wang, J.S., Xue, K.S., Agaba, E., Nshakira, N. and Ghosh, S. (2019). Association between maternal aflatoxin exposure during pregnancy and adverse birth outcomes in Uganda. Maternal and Child Nutrition, vol 15, no 2, e12701.

Matumba, L., Monjerezi, M., Biswick, T., Mwatseteza, J., Makumba, W., Kamangira, D. and Mtukuso, A. (2014) A survey of the incidence and level of aflatoxin contamination in a range of locally and imported processed foods on Malawian retail market. Food Control, vol 39, pp. 87-91.

Matumba, L., Monjerezi, M., Khonga, E.B. and Lakudzala, D. (2011) Aflatoxins in sorghum, sorghum malt and traditional opaque beer in southern Malawi. Food Control, vol 22 no 2, pp. 266-68.

Matumba, L., Singano, L., Tran, B., Mukanga, M., Makwenda, B., Kumwenda, W., Mgwira, S., Phiri, S., Mataya, F., Mthunzi, T., Alfred, S., Madzivhandila, T., Mugabe, J., Bennett, B., Chancellor, T. (2018) Managing aflatoxin in smallholder groundnut production in Southern Africa: Paired comparison of the windrow and Mandela cock techniques. Crop Protection, vol 112, pp. 18-23.

Matumba, L., Van Poucke, C., Ediage, E.N., Jacobs, B. and De Saeger, S. (2015) Effectiveness of hand sorting, flotation/washing, dehulling and combinations thereof on the decontamination of mycotoxin-contaminated white maize. Food Additives \& Contaminants: Part A, vol 32, no 6, pp. 960-969.

Misihairabgwi J.M., Ezekiel, C.N., Sulyok, M., Shephard, G.S. and Krska, R. (2019) Mycotoxin contamination of foods in Southern Africa: A 10-year review (2007-2016), Critical Reviews in Food Science and Nutrition, vol 59, no 1, pp. 43-58. 
Mngqawa, P., Shephard, G.S., Green, I.R., Ngobeni, S.H., de Rijk, T.C. and Katerere, D.R. (2016) Mycotoxin contamination of home-grown maize in rural northern South Africa (Limpopo and Mpumalanga Provinces). Food Additives and Contaminants: Part B, vol 9, no 1 , pp. 38-45.

Mohale, S., Medina, A., Rodriguez, A., Sulyok, M. and Magen, N. (2013). Mycotoxigenic fungi and mycotoxins associated with stored maize from different regions of Lesotho. Mycotoxin Research, vol 29, no 4, pp. 209-219.

Mukanga, M., Derera, J., Tongoona, P. and Laing, M.D. (2010) A survey of pre-harvest ear rot diseases of maize and associated mycotoxins in south and central Zambia. International Journal of Food Microbiology, vol 141, pp. 213-221.

Mukanga, M., Matumba, L., Makwenda, B., Alfred, S., Sakala, W., Kanenga, K., Chancellor, T., Mugabe, J. and Bennett, B. (2019) Participatory evaluation of groundnut planting methods for pre-harvest aflatoxin management in Eastern Province of Zambia. Cahiers Agricultures. https://doi.org/10.1051/cagri/2019002.

Mupunga, I., Lebelo, S.L. Mngqawa, P., Rheeder, J.P. and Katerere, D.R. (2014) Natural occurrence of aflatoxins in peanuts and peanut butter from Bulawayo, Zimbabwe. Journal of Food Protection, vol 77, pp. 1814-1818.

Murashiki, T.C., Chidewe, C., Benhura, M.A., Maringe, D.T., Dembedza, M.P., Manema, L.R., Mvumi, B.M. and Nyanga, L.K. (2017) Levels and daily intake estimates of aflatoxin B1 and fumonisin B1 in maize consumed by rural households in Shamva and Makoni districts of Zimbabwe. Food Control, vol 72, pp. 105-109.

Mwalwayo, D.S. and Thole, B. (2016) Prevalence of aflatoxin and fumonisins (B1 C B2) in maize consumed in rural Malawi. Toxicology Reports, vol 3, pp. 173-179.

Ncube, E., Flett, B.C.C., Waalwijk, C. and Viljoen, A. (2010) Occurrence of aflatoxins and aflatoxin producing Aspergillus spp. associated with groundnut production in subsistence farming systems in South Africa. South African Journal of Plant and Soil, vol 27, no 2, pp. 195-198.

Njoroge, S.M.C., Kanenga, K., Siambi, M., Waliyar, F. and Monyo, E.S. (2016). Identification and toxigenicity of Aspergillus spp. from soils planted to groundnut in Eastern Zambia. Peanut Science, vol 43, pp. 148-156.

Nleya, N., Adetunji, M.C. and Mwanza, M. (2018) Current status of mycotoxin contamination of food commodities in Zimbabwe. Toxins, vol 10, no 5, pp. 89.

Ojiambo, P.S., Battilani, P., Cary, J.W., Blum, B.H, Carbone, I. (2018) Cultural and genetic approaches to manage aflatoxin contamination: recent insights provide opportunities for improved control. Phytopathology, vol 108, no 9, pp. 1024-1037.

Probst, C., Bandyopadhyay, R. and Cotty, P. (2014) Diversity of aflatoxin-producing fungi and their impact on food safety in sub-Saharan Africa. International Journal of Food Microbiology, vol 174, pp. 113-122.

Rheeder, J.P., Van der Westhuizen, L., Imrie, G. and Shephard, G.S. (2016) Fusarium species and fumonisins in subsistence maize in the former Transkei region, South Africa: a multiyear study in rural villages. Food Additives and Contaminants: Part B, vol 9 no 3, pp. 176-184.

Richard, J.L. (2007) Some major mycotoxins and their mycotoxicosis - An overview. International Journal of Food Microbiology, vol 119, nos 1-2, pp. 3-10.

Schmidt, M., Zannini, E. and Arendt, E.K. (2018) Recent advances in physical post-harvest treatments for shelf-life extension of cereal crops. Foods, vol 7, no 4, p. 45.

Sharma, R.R., Singh, D. and Singh, R. (2009) Biological control of postharvest diseases of fruits and vegetables by microbial antagonists: A review. Biological Control, vol 50, no 3, pp. 205-221.

Shephard, G.S. (2008) Impact of mycotoxins on human health in developing countries. Food Additives \& Contaminants: Part A, vol 25, no 2, pp. 146-151. 
Shephard, G.S., Burger, H.M., Gambacorta, L., Krska, R., Powers, S.P., Rheeder, J.P., Solfrizzo, M., Sulyok, M., Visconti, A. Warth, B. and van der Westhuizen, L. (2013) Mycological analysis and multimycotoxins in maize from rural subsistence farmers in the former Transkei, South Africa. Journal of Agricultural and Food Chemistry, vol 61, no 34, pp. 8232-8240.

Shephard, G.S., Van der Westhuizen, L., Katerere, D.R., Herbst, M. and Pineiro, M. (2010) Preliminary exposure assessment of deoxynivalenol and patulin in South Africa. Mycotoxin Research, vol 26, pp. 181-185.

Streit, E., Schatzmayr, G., Tassis, P., Tzika, E., Marin, D., Taranu, I., Tabuc, C., Nicolau, A., Aprodu, I., Puel, O., Oswald, I.P. (2012) Current situation of mycotoxin contamination and co-occurrence in animal feed - focus on Europe. Toxins, vol 4, no 10, pp. 788-809.

Udomkun, P., Wiredu, A.N., Nagle, M., Bandyopadhyay, R., Müller, J. and Vanlauwe, B. (2017) Mycotoxins in Sub-Saharan Africa: Present situation, socio-economic impact, awareness, and outlook. Food Control, vol 72, pp. 110-122.

Velmourougane, K. Bhat, R., Gopinandhan, T.N., Panneerselvam, P. (2011) Management of Aspergillus ochraceus and Ochratoxin-A contamination in coffee during on-farm processing through commercial yeast inoculation. Biological Control, vol 57, no 3, pp. 215-221.

Warth, B. Parich, A. Atehnkeng, J., Bandyopadhyay, R., Schuhmacher, R., Sulyok, M. and Krska, R. (2012) Quantitation of mycotoxins in food and feed from Burkina Faso and Mozambique using a modern LC-MS/MS multitoxin method. Journal of Agricultural and Food Chemistry, vol 60, pp. $9352-9363$.

World Bank. (2011) Missing food - The case of postharvest grain losses in Sub-Saharan Africa. World Bank - FAO - Natural Resources Institute. World Bank Report 60371AFR, 2011.

Wu, F. (2015) Global impacts of aflatoxin in maize: Trade and human health. World Mycotoxin Journal, vol 8, no 2, pp. 137-142.

Wu, F. and Khlangwiset, P. (2010) Health economic impacts and cost-effectiveness of aflatoxin reduction strategies in Africa: Case studies in biocontrol and postharvest interventions. Food Additives and Contamination A, vol 27, pp. 496-509. 